\title{
DAMPAK SOSIAL-EKONOMI MASUKNYA PENGARUH INTERNET DALAM KEHIDUPAN REMAJA DI PEDESAAN
}

\author{
Socio-Economic Impacts by the Internet Usage of Teenagers in Villages
}

Putri Ekasari ${ }^{*}$ dan Arya Hadi Dharmawan

Departemen Sains Komunikasi dan Pengembangan Masyarakat, Fakultas Ekologi Manusia, IPB

*)Email : ekasariputri@yahoo.com

Diterima 10 Februari 2012 / Disetujui 2 Apri 2012

\begin{abstract}
The study was done in two village, they are Cibatok I Village and Pangradin Village, The Bogor District of West Java, Indonesia. The purposes of this study were 1) to analyse and determine the impacts of the use of internet in teenagers characteristics to internet usage pattern in two villages 2) to analyze the socioeconomic impact brought by internet usage pattern of teenagers in two villages. This study was approached by using quantitative method supported by qualitative method. Data obtained through observation, depth interviews and interviews using questionnaires. Meanwhile, the results of this study showed 1) The differences of internet usage pattern in the two villages 2) The availability of internet access in Cibatok I Village have made impacts to the socio-economic changes of teenagers life. Meanwhile, it is not clearly seen in teenagers live at Pangradin Village.
\end{abstract}

Keywords: Information and Communication Technology (ICT), Social Change, Internet, Cyber Society, Rural Communities, Teenagers, Socio-Economic Impacts.

\section{PENDAHULUAN}

\section{Latar Belakang}

Kemajuan Teknologi Informasi dan Komunikasi atau Information Communication and Technology (ICT) menjadi sangat pesat. Hal ini terjadi pada negara-negata di dunia, baik negara-negara maju maupun negara berkembang di Asia, termasuk Indonesia, sebagai akibat terjadinya revolusi interaksi sosial. Interaksi sosial merupakan syarat utama terjadinya aktivitas-aktivitas sosial. Menurut Soekanto (1974), terdapat dua syarat utama dalam sebuah interaksi sosial, yaitu kontak sosial dan komunikasi. Perkembangan teknologi dewasa ini, telah menyebabkan seseorang melakukan kontak sosial tidak hanya melalui hubungan badaniyah, tetapi juga melalui hubungan jarak jauh yang dijembatani oleh media komunikasi seperti internet. Menurut Roselin (2010), perkembangan teknologi internet juga tidak saja mampu menciptakan masyarakat dunia global, namun mampu menciptakan suatu transformasi dalam ruang gerak kehidupan baru bagi masyarakat, sehingga tanpa disadari manusia telah hidup dalam dua kehidupan yaitu kehidupan masyarakat nyata dan kehidupan masyarakat maya (cyber community). Melalui internet, memungkinkan seseorang melakukan kontak atau hubungan secara tidak langsung dengan komunitas dunia maya lainnya.

Di Indonesia, perubahan dalam tatanan kehidupan masyarakat juga telah dirasakan akibat masuknya pengaruh internet. Teknologi ini sudah dapat diakses oleh berbagai kalangan masyarakat. Remaja sebagai salah satu pengguna fasilitas internet belum mampu memilah aktivitas internet yang bermanfaat. Mereka juga cenderung mudah terpengaruh oleh lingkungan sosial tanpa mempertimbangkan terlebih dahulu efek positif atau negatif yang akan diterima saat melakukan aktivitas internet. Menurut Sarwono (2004), remaja berada pada tahap krisis identitas, cenderung mempunyai rasa keingintahuan yang tinggi, selalu ingin mencoba hal-hal baru, mudah terpengaruh dengan teman-teman sebayanya (peer groups).

Pada saat ini, perkembangan internet tidak hanya terbatas di wilayah perkotaan. Di pedesaan, konsep tentang desa dan masyarakatnya saat ini telah mengalami perubahan yang cukup besar akibat berkembangnya teknologi informasi, seperti internet. Adanya internalisasi nilai-nilai budaya barat akibat mudahnya akses teknologi internet di pedesaan telah membawa dampak terhadap perubahan gaya hidup masyarakat di pedesaan, terutama di kalangan remaja desa. Gaya hidup remaja desa pada masa dahulu selalu diidentikkan dengan gaya hidup yang dipengaruhi oleh nilai-nilai agama dan budaya setempat (Hastuti dan Sudarwati 2007).

Desa Cibatok I merupakan salah satu desa yang terletak di Kecamatan Cibungbulang, Kabupaten Bogor, Provinsi Jawa Barat. Pada awalnya, desa ini merupakan daerah yang masyarakatnya sebagian besar bermata-pencaharian di bidang pertanian. Pada tahun 2010, Pemerintah 
Kabupaten Bogor mencanangkan Desa Cibatok I sebagai salah satu Desa Mandiri ${ }^{1}$ dari delapan desa terpilih di Kabupaten Bogor. Hal ini menyebabkan desa tersebut telah dilengkapi dengan berbagai fasilitas yang memadai seperti sarana kesehatan, pendidikan, tempat ibadah, dan lain-lain. Desa Cibatok I sudah memiliki sarana telekomunikasi seperti jaringan telepon dan jaringan internet yang sangat baik. Ketersediaan akses jaringan internet dapat dilihat semakin banyaknya kepemilikan usaha warung internet yang selalu ramai dikunjungi oleh masyarakat, baik dewasa, remaja, maupun anak-anak. Di Sekolah Menengah Atas (SMA) 1 Cibungbulang yang terletak di Desa Cibatok 1, sudah difasilitasi Wifi atau Hotspot sehingga setiap siswa dan guru sudah dapat mengakses internet secara cepat

Desa Pangradin merupakan salah satu desa yang terletak di Kecamatan Jasinga, Kabupaten Bogor, Provinsi Jawa Barat. Fasilitas jaringan telekomunikasi seperti jaringan telepon dan internet di wilayah ini masih belum memadai. Jaringan telepon masih mengalami hambatan sulitnya mendapatkan sinyal yang cukup baik. Untuk jaringan internet, di desa ini baru terdapat satu warung internet yang bisa diakses oleh masyarakat.

\section{Perumusan Masalah}

Berdasarkan latar belakang di atas, maka rumusan masalah yang dikaji dalam penelitian ini sebagai berikut:

1. Bagaimana pengaruh karakteristik remaja terhadap pola penggunaan internet di Desa Cibatok I dan Desa Pangradin?

2. Apakah terdapat perbedaan terjadinya perubahan sosial yang dilihat dari aspek sosial-ekonomi masuknya internet dalam kehidupan remaja di desa yang akses terhadap internet dengan desa yang kurang akses terhadap internet?

\section{Tujuan Penelitian}

Tujuan penelitian ini secara umum untuk mempelajari dampak sosial-ekonomi masuknya internet dalam kehidupan remaja di pedesaan. Adapun secara spesik tujuannya adalah untuk mengetahui dan menganalisis:

1. Menganalisis pengaruh karakteristik remaja terhadap pola penggunaan internet di Desa Cibatok I dan Desa Pangradin.

2. Menganalisis dan membandingkan terjadinya perubahan sosial yang dilihat dari aspek sosialekonomi masuknya internet dalam kehidupan remaja di desa yang akses terhadap internet dengan desa yang kurang akses terhadap internet.

\footnotetext{
${ }^{1}$ Desa Mandiri merupakan program pembangunan yang berbasis pada pengembangan potensi desa agar masyarakat desa mempunyai kemandirian, serta tidak mengandalkan wilayah perkotaan untuk memenuhi seluruh kebutuhan hidup. Indikator yang harus dicapai pada program tersebut adalah Indeks Pembangunan Manusia (IPM) dengan upaya ke arah peningkatan di bidang Kesehatan, Pendidikan dan Ekonomi. [Internet]. (Diunduh 15 Januari 2012). Dapat diunduh di www.cibatoksatu.com.
}

\section{Kegunaan Penelitian}

Penelitian ini diharapkan dapat berguna bagi seluruh kalangan baik bagi sivitas akademika, masyarakat umum, maupun bagi pemerintah. Adapun manfaat yang diharapkan diperoleh masing-masing pihak adalah sebagai berikut:

1. Bagi penulis tulisan ini berguna sebagai landasan awal untuk melakukan studi lapang/skripsi selanjutnya dan memperoleh pemahaman serta pengetahuan baru terkait dampak sosial-ekonomi masuknya internet bagi masyarakat di pedesaan.

2. Bagi civitas akademik diharapkan tulisan ini menjadi referensi dalam melakukan penelitian terkait dampak dari internet bagi masyarakat di pedesaaan.

3. Bagi pemerintah dan masyarakat diharapkan tulisan ini dapat menjadi alternatif untuk membuat suatu program terkait solusi pengendalian dampak negatif internet.

\section{PENDEKATAN TEORITIS}

\section{Tinjauan Pustaka}

\section{Masyarakat Global}

Masyarakat adalah kelompok-kelompok orang yang menempati sebuah wilayah (teritorial) tertentu, yang hidup dalam waktu relatif lama, saling berkomunikasi, memiliki simbol-simbol dan aturan tertentu serta sistem hukum yang mengontrol tindakan anggota masyarakat, memiliki sistem stratifikasi, sadar sebagai bagian dari anggota masyarakat tersebut, serta relatif dapat menghidupi dirinya sendiri (Bungin 2009).

Perkembangan teknologi informasi telah mengubah masyarakat dunia, dari masyarakat dunia lokal menjadi masyarakat dunia global, yaitu sebuah dunia yang sangat transparan terhadap perkembangan informasi, transportasi, serta teknologi yang begitu cepat dan begitu besar mempengaruhi peradaban umat manusia. Perkembangan teknologi informasi juga tidak saja mampu menciptakan masyarakat dunia global, namun secara materi mampu mengembangkan ruang gerak kehidupan baru bagi masyarakat, sehingga tanpa disadari, komunitas manusia telah hidup dalam dua dunia kehidupan (Bungin 2006), yaitu:

1. Dunia nyata, sebuah kehidupan masyarakat yang secara indrawi dapat dirasakan sebagai sebuah kehidupan nyata dimana hubungan-hubungan sosial sesama anggota masyarakat dibangun melalui penginderaan. Secara nyata, kehidupan masyarakat manusia dapat disaksikan sebagaimana apa adanya.

2. Dunia maya, sebuah kehidupan masyarakat yang tidak dapat secara langsung diindera melalui penginderaan manusia, namun dapat dirasakan dan disaksikan sebagai sebuah realitas.

\section{Perubahan Sosial dan Kebudayaan Masyarakat}

Setiap manusia selama hidupnya pasti mengalami perubahan-perubahan. Perubahan tersebut dapat mengenai nilai-nilai sosial, norma-norma sosial, pola-pola perilaku, 
organisasi, susunan-susunan lembaga masyarakat lapisanlapisan dalam masyarakat, kekuasaan dan wewenang, interaksi sosial, dan sebagainya (Soekanto 1987). Perubahan sosial adalah segala perubahan-perubahan dalam lembaga-lembaga kemasyarakatan yang mempengaruhi sistem sosialnya, termasuk di dalamnya nilai-nilai, sikap-sikap dan pola-pola perilaku diantara kelompok-kelompok masyarakat (Soemardjan 1962). Perubahan sosial dalam masyarakat telah menyebabkan perubahan dalam struktur sosial dan kebudayaan.

\section{a. Perubahan Struktur Sosial}

Kehadiran teknologi informasi juga telah menyebabkan perubahan dalam struktur sosial dalam suatu masyarakat. Perubahan struktur sosial dapat dilihat dari perubahan pada ciri hubungan antara bagian-bagian dari struktur sosial (Harper 1989). Internet merupakan suatu bentuk teknologi yang menyediakan berbagai metode kehidupan dunia maya yang mirip dengan metode kehidupan dunia nyata. Munculnya media sosial online menyebabkan masyarakat pada saat ini lebih cenderung menyukai menjalin pertemanan yang lebih erat di dunia maya dibandingkan pertemanan yang dijalin secara langsung di dunia nyata. Hal ini menunjukkan adanya perubahan hubungan yang menyebabkan seseorang lebih tidak menghargai orang lain yang ada di dekatnya hanya demi berkomunikasi dengan teman yang jauh secara fisik.

\section{b. Perubahan Kebudayaan}

Kebudayaan didefinisikan oleh Koentjaraningrat (1979) sebagai keseluruhan sistem gagasan, tindakan, dan hasil karya manusia dalam rangka kehidupan masyarakat yang dijadikan milik manusia dengan cara memepelajarinya. William Ogburn (1922) mengemukakan bahwa ruang lingkup perubahan-perubahan sosial mencakup unsurunsur kebudayaan baik yang materiil mapupun immateriil seperti nilai, norma, ide, dan ideologi. Internet merupakan salah satu contoh kebudayaan materiil yang telah berdampak pada terjadinya pergeseran atau perubahan pada kebudayaan immateriil di masyarakat. Pada saat ini, seseorang yang menjadi bagian dari masyarakat maya cenderung tidak menghargai normanorma kehidupan di dunia nyata, terutama di lingkungan sekitarnya.

\section{Masyarakat Maya : Bentuk Perubahan Sosial dalam Kehidupan Manusia}

Teten dan Scott (2005) menguraikan definisi komunitas dunia maya sebagai sekumpulan dari orang-orang yang berada di ruang online dimana secara individu datang bersama untuk melakukan koneksi, interaksi, dan saling mengenal lebih dalam seiring dengan waktu. Perubahan sosial dalam masyarakat maya telah membentuk sebuah metode kehidupan maya yang dikembangkan dari model kehidupan nyata. Perubahan tersebut mencakup adanya interaksi dan kehidupan dalam masyarakat maya dan membangun kebudayaan masyarakat maya.

a. Interaksi sosial

Dua pola proses interaksi sosial masyarakat dunia maya, yaitu:
1. Proses sosial disosiatif, terjadi ketika beberapa anggota masyarakat maya terlibat dalam proses persaingan, atau bahkan konflik dengan sesama warga masyarakat maya.

2. Proses sosial asosiatif, memberikan peluang kepada komunitas maya, baik intra maupun antar jaringan, melakukan kerja sama di antara mereka (Bungin 2008 :159).

\section{b. Kebudayaan dan Masyarakat Maya}

Masyarakat maya menciptakan culture universal yang dapat dijelaskan sebagaimana yang dimiliki oleh masyarakat nyata:

1. Peralatan dan perlengkapan hidup masyarakat maya adalah teknologi informasi yang umumnya dikenal dengan mesin komputer dan mesinmesin elektronik lain yang membantu kerja atau dibantu oleh mesin komputer.

2. Mata pencaharian dan sistem-sistem ekonomi. Masyarakat maya memiliki mata pencaharian yang sangat menonjol dan spsesifik dalam bentuk menjual jasa dengan sistem ekonomi substansi.

3. Sistem kemasyarakatan yang dikembangkan dalam masyarakat maya adalah dalam bentuk sistem kelompok jaringan, baik intra maupun antar jaringan yang ada dalam masyarakat maya.

4. Bahasa masyarakat maya pada umumnya adalah bahasa inggris yang digunakan berdasarkan pada konvensi dan kreativitas pegguna bahasa ini, seperti menggunakan ikon-ikon tertentu untuk penggambaran dan sebagainya.

5. Karya komunitas maya adalah bagian dari karya seni pada umumnya. Semua karya masyarakat maya menempelkan seni sebagai ukuran pencitraan dan pemaknaan.

6. Sistem pengetahuan dikembangkan menggunakan proses pemberitahuan dan pembelajaran langsung secara trial and error. Karena itu, status sosial tertinggi dalam sistem pengetahuan adalah seberapa banyak seseorang menjadi tempat bertanya untuk memecahkan kasus-kasus tersebut.

7. Sistem religi masyarakat dunia maya adalah waktu dan keyakinan bahwa setiap misteri dalam dunia maya dapat dipecahkan (Bungin 2008:161).

\section{Definisi dan Karakteristik Remaja}

Istilah adolescence atau remaja berasal dari kata latin adolescere (kata bendanya adolescentia yang berarti remaja) yang berarti "tumbuh" atau "tumbuh menjadi dewasa" (Hurlock 1980). Secara teoritis dan empiris dari segi psikologis, rentangan usia remaja berada dalam usia 12 tahun sampai 21 tahun bagi wanita dan 13 tahun sampai 22 tahun bagi pria. Jika dibagi atas remaja awal dan remaja akhir, maka remaja awal berada dalam usia 12-13 tahun sampai 17-18 tahun, dan remaja akhir dalam rentang usia 17-18 tahun sampai 21 tahun (Mappiere 
1982). Menurut Gunarsa dan Gunarsa (1995), ciri-ciri yang menonjol dari remaja adalah:

1. Memiliki keadaan emosi yang labil

2. Timbulnya sikap menantang dan menentang orang lain. Hal itu dilakukan sebagai wujud remaja ingin merenggangkan hubungan maupun ikatan dengan orangtuanya

3. Memiliki sikap untuk mengeksplorasi atau keinginan untuk menjelajahi lingkungan alam sekitar

4. Memiliki banyak fantasi, khayalan, dan bualan

5. Remaja cenderung untuk membentuk suatu kelompok

Berdasarkan perkembangan psikososial, remaja dibagi menjadi tiga periode, yaitu remaja awal, remaja menengah, dan remaja akhir.

\section{Remaja Awal (Umur 10-14 Tahun)}

Karakteristik remaja awal yaitu mengalami percepatan pertumbuhan fisik dan seksual. Mereka sering membandingkan sesuatu dengan teman sebaya dan sangat mementingkan penerimaan oleh teman sebaya. Hal ini mengakibatkan cenderung mulai mengabaikan pengaruh yang berasal dari lingkungan rumah.

\section{Remaja Menengah (Umur 15-17 Tahun)}

Remaja menengah memiliki karakteristik, yaitu berkembangnya kesadaran diri, khususnya pada remaja putri. Mereka mulai memperhatikan pertumbuhan fisik dan memiliki citra tubuh yang cenderung salah.

\section{Remaja Akhir (Umur 18-21 Tahun)}

Remaja akhir ditandai dengan kematangan atau kesiapan menuju tahap kedewasaan dan lebih fokus pada masa depan, baik dalam bidang pendidikan, pekerjaan, seksual, dan individu. Karakteristik remaja akhir umumnya merasa nyaman dengan nilai dirinya dan pengaruh teman sebaya sudah mulai berkurang (Krummel, dkk 1996).

Menurut Soekanto (2002), pada masyarakat (dalam hal ini remaja) desa, ciri-ciri yang menonjol adalah kehidupan keagamaan remaja desa cenderung lebih kuat dibandingkan dengan remaja kota. Hal ini disebabkan oleh kehidupan masyarakat desa yang cenderung ke arah agama (religious trend).

Perbedaan jenis kelamin remaja juga menyebabkan perbedaan-perbedaan dalam perilakunya. Remaja perempuan cenderung memiliki tingkat keintiman yang dalam dengan orang-orang di sekitarnya dibanding dengan remaja laki-laki. Hal ini dikarenakan laki-laki cenderung ingin menunjukkan kemandirian yang lebih dan adanya jarak dengan sekitarnya (Hurlock 1980). Psikologi sosial menjelaskan bahwa terdapat faktor-faktor yang dapat mempengaruhi perilaku seseorang, yaitu faktor personal dan faktor environmental (Rachmat 2002).

\section{Dampak Sosial-Ekonomi Internet}

Kebangkitan era digital sering kali merujuk pada sejarah penemuan "www" pada tahun 1999. Perkembangan dunia digital tampaknya juga tercermin di Indonesia. Pengguna internet, dalam 10 tahun terakhir ini, tumbuh sangat pesat. Pada tahun 2000, pengguna internet di Indonesia masih sekitar 2 juta orang. Namun, jumlah tersebut naik dalam tahun-tahun berikutnya. Pada tahun 2010, Indonesi berada di peringkat 16 dunia dalam jumlah pengguna internet (Manan 2011).

Menurut Horrigan (2000), terdapat dua hal mendasar yang harus diamati untuk mengetahui intensitas penggunaan intenet seseorang, yakni frekuensi internet yang sering digunakan dan lama menggunakan tiap kali mengakses internet yang dilakukan oleh pengguna internet. Tiga kategori pengguna internet berdasarkan intensitas internet (The Graphic, Visualization \& Usability Center, the Georgia Institute of Technology dalam Surya 2002), yaitu:

\section{1) Heavy users (lebih dari 40 jam per bulan) \\ 2) Medium users (antara 10 sampai 40 jam per bulan) \\ 3) Light users (kurang dari 10 jam per bulan)}

Saat ini, internet berdiri dengan kokoh sebagai bentuk baru media massa, bergabung dengan televisi, radio, dan media cetak.. Sebuah kajian pada tahun 2003 yang dilakukan oleh Harris Interactive and Teenage Research Unlimited untuk perusahaan media internet Yahoo menemukan bahwa anak muda berusia 13-24 tahu menghabiskan lebih banyak waktu untuk mengakses internet setiap minggunya dibandingkan menonton televisi (Hernandez 2005).

\section{Kerangka Pemikiran}

Sikap remaja desa terhadap kehadiran internet dipengaruhi oleh karakteristik remaja itu sendiri. Karakteristik remaja tersebut terdiri atas jenis kelamin, umur, status pendidikan, dan uang saku. Karakteristik yang dimiliki oleh seorang remaja akan berpengaruh terhadap pola penggunaan internet. Pola penggunaan internet berhubungan dengan intensitas penggunaan remaja dalam memanfaatkan akses internet, rutinitas/frekuensi waktu yang dihabiskan untuk bermain internet, dan jenis laman/situs yang sering dibuka oleh remaja desa.

Pada penelitian ini juga akan dilihat dampak yang ditimbulkan internet yang dilihat dari aspek sosial dan aspek ekonomi. Dampak sosial dalam penelitian ini diukur dari intensitas hubungan sosial dalam keluarga, intensitas hubungan yang dibina/dijalin oleh remaja di pedesaan antara teman di dunia nyata dengan temannya di dunia maya, alokasi waktu antara bermain internet dengan aktivitas lainnya luasnya jaringan sosial dunia maya yang tidak terbatas oleh territorial, tingginya perilaku negatif, rendahnya tingkat penghargaan terhadap nilai-nilai dan norma, serta terjadi perubahan pada pola pikir atau ideologi remaja. Hal ini sebagaimana yang terlihat pada Gambar 1.

Dari Gambar 1 juga dapat dilihat bahwa dampak ekonomi dalam penelitian ini diukur dari alokasi uang saku yang diterima remaja dari orang tua, dan tingkat pengeluaran/konsumsi biaya untuk bermain internet di warung internet (warnet) serta membeli pulsa untuk mengakses internet melalui telepon seluler. 


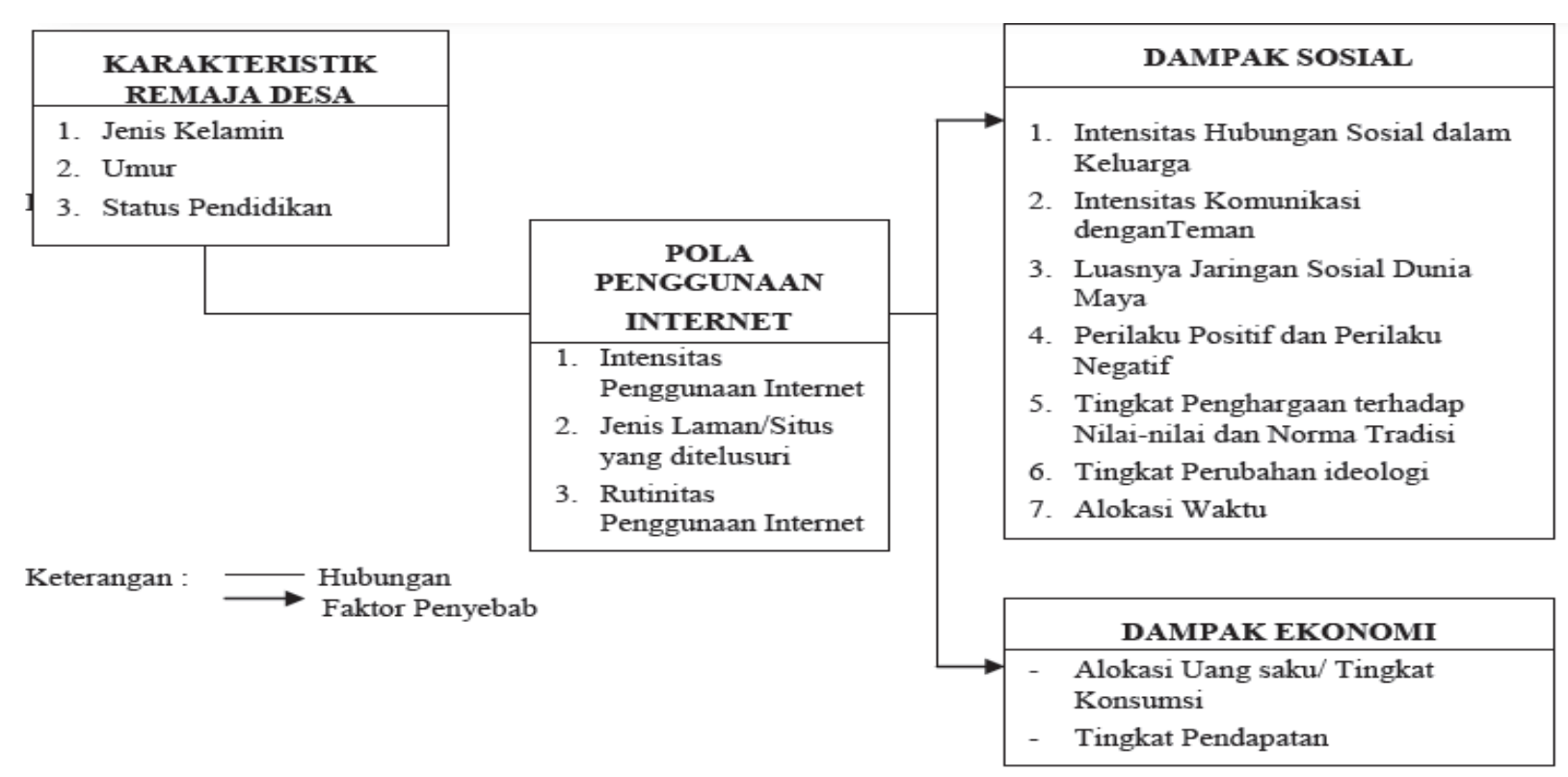

\section{Hipotesis Penelitian}

Berdasarkan kerangka berfikir dapat disusun hipotesis penelitian sebagai berikut:

1. Diduga karakteristik remaja di Desa Cibatok I dan Desa Pangradin memiliki hubungan positif dengan pola penggunaan internet.

2. Diduga terdapat perbedaan kedalaman perubahan sosial dalam aspek sosial-ekonomi antara remaja di desa yang akses terhadap internet dengan remaja di desa yang kurang akses terhadap internet.

\section{PENDEKATAN LAPANGAN}

\section{Metode Penelitian}

Metode penelitian ini menggunakan pendekatan kuantitatif yang didukung oleh pendekatan kualitatif. Dalam pendekatan kuantitatif, penelitian ini menggunakan metode penelitian survey. Penelitian survey adalah penelitian yang mengambil sampel dari satu populasi dan menggunakan kuesioner sebagai alat pengumpulan data pokok (Singarimbun dan Effendi 1989). Dalam pendekatan kualitatif, penelitian ini menggunakan metode studi kasus, pengamatan, dan wawancara.

Pendekatan kuantitatif digunakan untuk mengetahui dampak sosial-ekonomi masuknya pengaruh internet dalam kehidupan remaja dengan membandingkan antara desa yang sudah memiliki akses internet yang memadai dengan desa yang memiliki akses internet rendah. Metode kualitatif dilakukan untuk mendapatkan informasi yang lebih dalam mengenai perkembangan internet di kedua desa melalui teknik wawancara.

\section{Lokasi dan Waktu Penelitian}

Penelitian ini dilakukan di dua desa yaitu Desa Cibatok I, Kecamatan Cibungbulang, Kabupaten Bogor, Jawa Barat dan Desa Pangradin, Kecamatan Jasinga, Kabupaten Bogor, Jawa Barat. Pemilihan lokasi tersebut dilakukan secara sengaja (purposive) dengan beberapa alasan:
1. Desa Cibatok I merupakan salah satu desa yang pada tahun 2010 ditetapkan sebagai salah satu desa peradaban oleh pemerintah dari delapan desa terpilih di Kabupaten Bogor. Hal ini menyebabkan desa tersebut telah dilengkapi dengan berbagai fasilitas yang memadai seperti sarana kesehatan, pendidikan, tempat ibadah, akses jaringan telekomunikasi dan internet, dan lain-lain. Sedangkan Desa Pangradin merupakan desa yang masih jauh dari keterdedahan akses telekomunikasi. Hal ini disebabkan belum berkembangnya warung internet dan masih jarangnya kepemilikian telepon genggam yang memiliki akses internet.

2. Semakin banyaknya kehadiran warung internet dan jaringan telekomunikasi yang baik di Desa Cibatok I menyebabkan remaja di wilayah tersebut sudah dapat mengakses internet dengan mudah. Sedangkan warung internet dan jaringan telekomunikasi di Desa Pangradin masih sangat terbatas sehingga remaja di wilayah tersebut cukup sulit dalam mengakses internet.

3. Kemudahan akses bahasa dan tempat.

Kegiatan penelitian meliputi penyusunan proposal skripsi, kolokium, pengambilan data lapangan, penulisan draft skripsi, sidang skripsi, dan perbaikan laporan penelitian. Waktu penelitian dilakukan pada bulan Oktober sampai November Tahun 2011.

\section{Kerangka Sampling}

Kerangka sampling dalam penelitian ini terdiri dari dua desa yang berbeda Kedua desa ini dipilih secara purposive, yaitu berdasarkan hasil pengamatan dan informasi yang terpercaya. Desa Cibatok I merupakan desa yang sudah memiliki ketersediaan akses internet yang sangat baik. Hal ini dibuktikan dari sudah tersedianya fasilitas warung internet dalam jumlah yang cukup banyak, jaringan telekomunikasi yang baik, wifi zone sekolah, dan kepemilikan internet di rumah. Sementara Desa Pangradin merupakan desa yang belum memiliki fasilitas internet yang baik. Keterbatasan untuk 
dapat mengakses internet yang dtunjukkan masih minimnya warung internet, sinyal telekomunikasi yang masih sulit, dan kurangnya kepemilikian komputer pribadi menyebabkan desa ini masih sangat awam dalam menggunakan fasilitas internet.

Selanjutnya dipilih remaja dari kedua desa yang terbagi menjadi dua kelompok dengan karakteristik yang berbeda. Kelompok pertama merupakan remaja Desa Cibatok I, Kecamatan Cibungbulang. Remaja ini dipilih secara purposive, yaitu dengan meminta data seluruh siswa SMAN 1 Cibungbulang dari kelas X sampai dengan kelas XII. Alasan dipilihnya siswa-siswa SMAN 1 Cibungbulang dikarenakan siswa-siswa tersebut memiliki kriteria umur yang sesuai dengan objek penelitian, yaitu remaja yang berumur 15-20 tahun. Disamping itu, untuk mempermudah mencari data siswa yang tinggal di Desa Cibatok I juga menjadi alasan dipilihnya SMAN 1 Cibungbulang untuk dijadikan kerangka sampling. Dari daftar siswa yang berjumlah 991 orang, kembali dipilih secara purposive remaja desa yang tinggal di Cibatok I dan sudah pernah mengakses internet dengan jumlah 43 orang. Daftar siswa SMAN 1 Cibungbulang yang tinggal di Desa Cibatok I tersebut merupakan kerangka sampling dari penelitian ini. Dari sini dipilih secara acak 30 responden untuk dijadikan sampel penelitian.

Kelompok remaja kedua merupakan remaja Desa Pangradin, Kecamatan Jasinga. Remaja didata berdasarkan informasi yang diberikan oleh sekretaris desa. Sekretaris Desa merupakan orang yang menyimpan berkas-berkas kartu keluarga sehingga mengetahui namanama remaja yang memiliki rentang umur dari 15-20 tahun. Daftar nama tersebut merupakan kerangka sampling dari penelitian ini, dimana terdapat 81 orang remaja desa dengan kriteria umur yang telah ditentukan dan sudah pernah mengakses internet. Kemudian dipilih secara acak 30 responden untuk dijadikan sampel penelitian.

\section{Teknik Pengolahan dan Analisis Data}

Teknik pengolahan dan analisis data yang digunakan dalam penelitian ini dilakukan dengan perlakuan yang berbeda sesuai dengan jenis data yang diperoleh dengan pendekatan penelitian berbeda, yakni data yang diperoleh dari pendekatan kualitatif dan dari data kuantitatif. Data yang diperoleh dari pendekatan kualitatif akan diolah melalui tiga tahap analisis data kualitatif, yakni reduksi data, penyajian data dan penarikan kesimpulan. Sugiyono (2008) mendefinisikan tahap-tahap analisis data sebagai berikut:

1. Reduksi data: merangkum, memilih hal-hal pokok, memfokuskan pada hal-hal yang penting, dan mencari tema serta pola data yang diperoleh;

2. Penyajian data: menyajikan data dalam bentuk uraian singkat, bagan, hubungan antar kategori, flowchart, dan lain-lain; untk mempermudah peneliti dalam mengorganisir data, meyusun pola dan memahami data yang diperoleh;

3. Penarikan kesimpulan yang menghasilkan temuan baru atas obyek penelitian.
Data kuantitatif diperoleh melalui penyebaran kuesioner di lapangan yang diperkuat dengan teknik wawancara langsung dengan responden. Pengolahan data dilakukan dengan tabel frekuensi untuk menghitung persentase jawaban responden yang dibuat dalam bentuk tabulasi silang untuk mengetahui hubungan antara dua variabel yaitu untuk melihat adanya pengaruh karakteristik responden dengan pola penggunaan internet dan dampak sosial-ekonomi akibat pola penggunaan internet tersebut.

\section{GAMBARAN UMUM LOKASI PENELITIAN}

\section{Gambaran Umum Wilayah Desa Cibatok I}

\section{Kondisi Geografis}

Desa Cibatok I merupakan salah satu desa di wilayah Kecamatan Cibungbulang, Kabupaten Bogor, Provinsi Jawa Barat. Secara administratif, Desa Cibatok I terbagi ke dalam 4 dusun, 9 Rukun Warga (RW), dan 29 Rukun Tetangga (RT). Sebelah Utara Desa Cibatok I berbatasan dengan Desa Rawabogo, Sebelah Selatan berbatasan dengan Desa Alam Endah, Sebelah Timur berbatasan dengan Sungai Ciaruteun, dan Sebelah Barat berbatasan dengan Sungai Cibungbulang.

\section{Kondisi Sosial-Ekonomi Masyarakat Desa Cibatok I}

\section{a. Kependudukan}

Penduduk di Desa Cibatok I sebagian besar berada pada usia produktif yang berkisar antara 15 tahun hingga 65 tahun yaitu sebanyak 5.737 jiwa dari total jumlah penduduk. Untuk penduduk yang usianya belum produktif yaitu usia kurang dari 15 tahun sebanyak 2.246 jiwa dari total jumlah penduduk.

\section{b. Ketersediaan Fasilitas Umum}

Desa Cibatok terletak di Kecamatan Cibungbulang, Kabupaten Bogor, Provinsi Jawa Barat. Desa ini sudah memiliki fasilitas umum yang sangat baik seperti listrik, prasana pemerintahan desa, prasarana pendidikan, prasarana peribadatan, prasarana kesehatan, dan prasarana perekonomian. Disamping itu, Desa Cibatok I sudah memiliki sarana telekomunikasi seperti jaringan telepon dan jaringan internet yang sangat baik.

\section{c. Pendidikan}

Tingkat pendidikan masyarakat Desa Cibatok I sudah tergolong tinggi. Kesadaran masyarakat untuk melanjutkan sekolah hingga ke perguruan tinggi negeri sangat besar. Hal ini juga didukung dengan ketersediaan fasilitas sarana pendidikan di desa tersebut dan akses yang tidak terlalu jauh dari pusat pendidikan. Salah satu sekolah yang berada di Desa Cibatok I adalah Sekolah Menengah Atas Negeri (SMAN) 1 Cibungbulang. Sekolah ini sudah dilengkapi dengan berbagai fasilitas yang memadai, salah satunya yaitu fasilitas Hotspot.

\section{d. Agama}

Masyarakat Desa Cibatok I seluruhnya memeluk agama Islam, yaitu 7.983 orang (100 persen). Sejalan dengan hal ini, sarana peribadatan yang ada hanyalah masjid dan mushala. Kegiatan-kegiatan keagamaan yang rutin dilakukan, misalnya pengajian dan upacara hari besar agama Islam. Namun, tidak dipungkiri bahwa pengaruh- 
pengaruh budaya perkotaan sudah mulai masuk dalam wilayah Desa Cibatok I yang membuat lunturnya sedikit demi sedikit nilai-nilai agama, terutama akibat kehadiran internet. Banyak remaja dan anak-anak yang meninggalkan ibadahnya karena keasyikan bermain internet.

\section{e. Pranata Sosial, Budaya, dan Adat Istiadat}

Mayoritas masyarakat Desa Cibatok I adalah suku Sunda. Namun, saat ini sudah banyak masyarakat pendatang (Betawi, Jawa, Batak, Aceh, dan Minang) yang tinggal di wilayah ini. Hal ini menyebabkan masyarakat Desa Cibatok I hidup dalam keragaman suku/etnis. Untuk bahasa sehari-hari yang digunakan adalah bahasa Sunda. Keadaan nilai-nilai budaya masyarakat setempat dapat digolongkan relatif baik. Namun, kuatnya pengaruh luar telah membuat beberapa nilai-nilai budaya masyarakat sudah mulai memudar, seperti cara berpakaian, gaya hidup, dan lain-lain.

\section{f. Perekonomian}

Mayoritas masyarakat Desa Cibatok I memiliki mata pencaharian sebagai petani dan buruh tani. Hal ini dapat dilihat masih banyaknya lahan-lahan pertanian padi sawah, singkong, jagung, ubi jalar, dan lain-lain. Namun, sebagian besar masyarakatnya juga berprofesi sebagai pegawai negeri sipil. Ini memperlihatkan bahwa sudah tingginya kesadaran masyarakat Desa Cibatok I untuk memperbaiki perekonomian keluarga maupun di tingkat desa.

\section{Gambaran Umum Desa Pangradin}

\section{Kondisi Geografis}

Desa Pangradin merupakan salah satu dari 16 desa yang terletak di Kecamatan Jasinga, Kabupaten Bogor, Provinsi Jawa Barat. Secara administratif, Desa Pangradin terbagi ke dalam dua dusun, yakni Dusun Pangradin I dan Dusun Pangradin II. Keseluruhan dusun terbagi ke dalam 6 Rukun Warga (RW) dan 31 Rukun Tetangga (RT). Awalnya wilayah Desa Pangradin terbagi ke dalam tiga dusun. Namun ketika ada pemekaran wilayah, Dusun Pangradin III kini masuk ke dalam wilayah Desa Jugala Jaya.

\section{Kondisi Sosial-Ekonomi Masyarakat Desa Pangradin}

\section{Kependudukan}

Penduduk di Desa Pangradin sebagian besar berada pada usia produktif yang berkisar antara 15 tahun hingga 60 tahun yaitu sebanyak 2.184 jiwa. Untuk penduduk yang usianya belum produktif yaitu usia kurang dari 15 tahun sebanyak 1.230 jiwa dari total jumlah penduduk.

\section{Ketersediaan Fasilitas Umum}

Desa Pangradin terletak di Kecamatan Jasinga, Kabupaten Bogor Jawa Barat. Desa ini sudah memiliki fasilitas umum seperti sarana telekomunikasi, listrik, sarana angkutan, sarana dan prasarana perekonomian, sarana pendidikan, sarana ibadah, dan sarana kesehatan. Namun, untuk jaringan telepon dan internet masih mengalami kendala sulitnya mendapatkan sinyal yang cukup baik.

\section{Pendidikan}

Tingkat pendidikan masyarakat Pangradin masih relatif rendah. Minimnya tingkat pendidikan terjadi karena keterbatasan ekonomi dan kurang tersedianya fasilitas pendidikan di desa tersebut sehingga dibutuhkan jarak tempuh yang cukup jauh bila ingin melanjutkan pendidikan kejenjang yang lebih tinggi. Banyak remajaremaja desa yang putus sekolah dan akhirnya memilih bekerja sebagai tukang ojeg, penjual soto, atau berimigrasi ke kota.

\section{Agama}

Masyarakat Desa Pangradin mayoritas penduduknya beragam Islam, yaitu 6.444 orang (99 persen) dan sisanya satu orang (1 persen) menganut agama Kristen Katolik. Sejalan dengan hal ini, sarana peribadatan yang ada hanyalah masjid dan mushala. Kegiatan-kegiatan keagamaan rutin dilakukan, misalnya pengajian, peringatan hari besar agama, dan lain-lain. Namun, walaupun tidak semua masyarakat Desa Pangradin beragama islam, kerukunan antar umat beragam tetap dapat terjalin. Adanya penduduk yang bukan beragama Islam di lingkungan Desa Pangradin dapat diterima dengan baik.

\section{Pranata Sosial, Budaya dan Adat-Istiadat}

Mayoritas masyarakat Desa Pangradin adalah suku Sunda sehingga dalam tatanan kehidupan mereka pun tidak terlalu beragam. Keadaan nilai-nilai budaya masyarakat setempat dapat digolongkan relatif baik, dimana penghargaan warga masyarakat terhadap orang tua, guru, tokoh masyarakat, tetangga, dan pemerintah setempatmasih tinggi. Untuk jenis kejahatan seperti oencurian, penodongan, dan mabuk-mabukan jarang terjadi. Hal ini disebabkan karena nilai-nilai keagamaan sangat dijunjung tinggi oleh masyarakat Desa Pangradin.

\section{Perekonomian}

Wilayah Desa Pangradin berada di pedalaman Kabupaten Bogor sehingga mayoritas masyarakatnya bekerja sebagai petani dan buruh tani. Selain itu, beberapa warga Desa Pangradin ada yang melakukan migrasi ke kota untuk mencari pekerjaan. Maka dapat disimpulkan hampir sebagian besar masyarakat Desa Pangradin menggunakan pola nafkah ganda dalam kehidupannya.

\section{PENGARUH KARAKTERISTIK REMAJA TERHADAP POLA PENGGUNAAN INTERNET}

\section{Karakteristik Responden}

Responden di kedua lokasi penelitian memiliki jumlah yang sama, yaitu 30 orang di Desa Cibatok I dan 30 orang di Desa Pangradin. Masing-masing desa dipilih 15 remaja laki-laki dan 15 remaja perempuan. Hal ini sengaja dilakukan dengan alasan sebagai berikut:

1. Untuk melihat perbandingan pengaruh internet di desa yang sudah memiliki ketersediaan akses internet yang sangat baik dengan desa yang memiliki keterbatasan internet dalam persentase yang sama.

2. Responden laki-laki memiliki persentase jumlah yang sama dengan responden perempuan, baik di Desa Cibatok I maupun Desa Pangradin. Hal ini dilakukan untuk melihat adanya perbedaan dalam 
pola penggunaan internet antara laki-laki dan perempuan yang ada di kedua desa.

Dalam penelitian ini, golongan umur responden dikategorikan menjadi tiga, yaitu rendah (Umur 15-16 Tahun), Sedang (Umur 17-18 Tahun), dan Tinggi (Umur 19-20 Tahun). Perbedaan umur antara Desa Cibatok I dan Desa Pangradin tidak terlalu jauh. Umumnya responden di kedua desa tersebut didominasi oleh golongan umur rendah, yaitu 15-16 tahun, dengan persentase di Desa Cibatok I sebanyak 19 orang dan Desa Pangradin sebanyak 20 orang. Hal ini disebabkan oleh beberapa faktor berikut:

1. Populasi di Desa Pangradin dipilih secara acak sehingga penyebaran golongan umur tidak merata. Disamping itu, data yang diperoleh melalui aparat desa, remaja di Desa Pangradin banyak memiliki rentang umur 15-16 tahun.

2. Populasi di Desa Cibatok I dipilih secara purposive. Dari data siswa yang diperoleh melalui pihak SMAN 1 Cibungbulang, siswa yang berdomisili di Desa Cibatok I banyak yang masih duduk di bangku kelas X dengan rata-rata memiliki kelahiran tahun 1996.

3. Untuk Desa Cibatok I, tidak ada responden yang memiliki umur 19 tahun dan 20 tahun. Hal ini dikarenakan, seluruh responden merupakan siswa SMAN 1 Cibungbulang yang memiliki rentang umur dari 15-18 tahun. Sementara Desa Pangradin, umur responden cenderung beragam karena tidak dipilih secara purposive.

Dilihat dari tingkat pendidikan, dalam penelitian ini menunjukkan beberapa hal, yaitu:

a. Remaja di Desa Cibatok I sudah banyak yang melanjutkan ke jenjang pendidikan yang lebih tinggi karena didukung oleh sarana dan prasarana pendidikan yang sudah sangat baik di desa tersebut serta kemampuan orang tua dalam membiayai sekolah anak-anak mereka.

b. Remaja di Desa Pangradi banyak yang putus sekolah dikarenakan kurangnya sarana dan prasarana pendidikan yang tersedia di desa tersebut, akses pendidikan yang cukup jauh, dan keterbatasan faktor ekonomi sehingga para orangtua tidak mampu untuk membiayai sekolah mereka. Hal ini menyebabkan mereka akhirnya lebih memilih bekerja atau menikah di usia muda.

\section{Pola Penggunaan Internet}

\section{Jenis Situs dan Rutinitas Pemakaian Internet}

Banyak teknologi yang telah menyediakan fasilitas internet sehingga memudahkan manusia untuk mengakses internet. Dalam penelitian ini, media koneksi internet dikategorikan menjadi empat, yaitu warung internet, ponsel/telepon genggam, Wifi/Hotspot, dan komputer pribadi/laptop. Dari hasil penelitian diketahui bahwa ratarata remaja di kedua desa mengakses internet melalui warung internet (warnet) dengan persentase masing masing sebesar 47 persen (14 orang di Desa Cibatok I) dan 73 persen (22 orang) di Desa Pangradin. Di Desa Cibatok I, remaja lebih memilih untuk bermain internet di warnet karena akses yang mudah dan biaya yang dikeluarkan juga tidak terlalu mahal. Untuk di Desa Pangradin, remaja hanya bisa mengakses internet melalui warnet atau ponsel.

\section{Ragam Situs Internet}

Jenis situs merupakan ragam situs yang dibuka oleh responden ketika mengakses internet. Dalam penelitian ini, jenis situs dikategorikan menjadi enam, yaitu: situs pendidikan, situs agama, situs pengetahuan umum, situs hiburan, situs jejaring sosial, dan situs pornografi. Dari pengkategorian jenis situs, akan dilihat juga rutinitas atau tingkat kerutinan responden dalam membuka situs-situs internet tersebut. Dalam hal ini, rutinitas dikategorikan menjadi tiga, yaitu: sering, kadang-kadang, dan tidak pernah. Dari hasil penelitian diketahui bahwa rata-rata remaja di Desa Cibatok I memiliki keinginan yang lebih tinggi untuk membuka situs pendidikan dibandingkan remaja di Desa Pangradin. Hanya 3 persen atau satu orang saja di Desa Pangradin yang mengaku pernah membuka situs pendidikan.

Rata-rata remaja di Desa Cibatok I lebih sering membuka situs hiburan dibandingkan remaja Pangradin. Hanya 17 persen (lima orang) remaja di Desa Cibatok I mengaku tidak pernah membuka situs hiburan. Sementara di Desa Pangradin, 70 persen (21 orang) remaja tidak pernah membuka situs hiburan. Remaja di Desa Cibatok I memiliki keinginan yang tinggi untuk membuka situs pengetahuan umum dibandingkan remaja di Desa Pangradin. Hanya 7 persen atau satu orang remaja di Desa Cibatok I mengaku tidak pernah membuka situs ini. Sedangkan 53 persen (16 orang) remaja di Desa Pangradin tidak pernah membuka situs pengetahuan umum.

Rata-rata remaja di Desa Cibatok I dan Desa Pangradin jarang membuka situs pornografi. Hanya 30 persen (9 orang) remaja di Desa Cibatok I dan 3 persen (1 orang) remaja di Desa Pangradin yang mengaku pernah membuka situs ini. Sementara itu, rata-rata remaja di Desa Cibatok I dan Desa Pangradin sama-sama memiliki rutinitas yang tinggi dalam membuka situs jejaring sosial. Hal ini menunjukkan bahwa media sosial tidak lagi memandang asal, golongan umur, status pendidikan, dan jenis kelamin. Sebagian besar remaja di kedua desa mengaku kecanduan untuk membuka situs jejaring sosial, terutama Facebook. Untuk situs agama, rata-rata keinginan atau minat remaja di kedua desa dalam mengakses situs ini cukup rendah.

\section{Prioritas Situs Internet yang Dibuka}

Dalam setiap mengakses situs-situs yang ada di internet, remaja memiliki prioritas situs atau situs yang didahulukan untuk dibuka ketika setiap kali membuka laman internet sebelum membuka situs-situs lainnya. Rata-rata remaja di kedua desa tersebut memprioritaskan situs jejaring sosial ketika mengakses internet. Mereka lebih dahulu membuka media sosial tersebut sebelum membuka laman atau situs lainnya. Hal ini menandakan bahwa situs jejaring menjadi situs yang sangat digemari oleh remaja di pedesaan, baik desa yang telah memiliki akses internet yang cukup baik maupun desa yang memiliki keterbatasan akses internet. 


\section{Tujuan Membuka Situs Internet}

Rata-rata remaja laki-laki di Desa Cibatok I dan Desa Pangradin sering membuka situs hiburan, seperti Youtube, 4shared, Game Online, dan lain-lain karena hobby yang mereka miliki. Biasanya mereka mengunjungi warung internet untuk bermain Game Online, menonton atau mendownload film-film terbaru. Mereka sering menghabiskan waktu berjam-jam di warung internet atau komputer pribadi hanya untuk bermain Game Online bersama teman-teman. Sementara itu, rata-rata tujuan remaja perempuan di Desa Cibatok I dan Desa Pangradin membuka situs internet adalah untuk menjalin pertemanan di dunia maya yang dapat dilakukan melalui situs jejaring sosial, seperti Facebook, Twitter, Hello, dan lain-lain.

Dalam penelitian ini, juga dilihat hubungan antara jenis kelamin responden dengan keragaman situs internet yang dibuka. Jenis kelamin dikategorikan menjadi dua, yaitu laki-laki dan perempuan. Sementara itu, ragam situs yang dibuka dikategorikan menjadi dua, yaitu : Tidak Beragam dan Beragam. Tabel 1 menyajikan data mengenai hubungan antara jenis kelamin dengan keragaman situs yang dibuka.

Tabel 1. Hubungan Antara Jenis Kelamin dengan Ragam Situs yang Dibuka di Desa Cibatok I dan Desa Pangradin

\begin{tabular}{lcccc}
\hline \multirow{3}{*}{ Jenis Kelamin } & \multicolumn{4}{c}{ Ragam Situs } \\
& Tidak Beragam & \multicolumn{2}{c}{ Beragam } \\
\hline Jumlah & Persentase (\%) & Jumlah & Persentase (\%) \\
\hline Laki-Laki & 4 & 13 & 26 & 87 \\
Perempuan & 12 & 40 & 18 & 60 \\
\hline
\end{tabular}

Dari data Tabel 1 dapat dijelaskan bahwa rata-rata remaja laki-laki lebih beragam dalam membuka situs internet dibandingkan remaja perempuan. Hal ini dikarenakan oleh beberapa hal berikut, yaitu:

1. Remaja laki-laki di Desa Cibatok I dan Desa Pangradin memiliki explosure atau keterdedahan terhadap internet yang lebih tinggi dibandingkan remaja perempuan.

2. Remaja perempuan yang ada di kedua desa tersebut cukup jarang mengakses internet dan lebih menyukai menonton televisi, membaca majalah, ataupun berkumpul bersama teman-temannya sehingga tidak terlalu banyak mengetahui situs-situs yang tersedia di internet.

Selanjutnya, dalam penelitian ini akan dilihat hubungan antara golongan umur mempengaruhi ragam situs yang dibuka oleh remaja di Desa Cibatok I dan Desa Pangradin. Adapun golongan umur dikategorikan menjadi tiga, yaitu: rendah (umur 15-16 tahun), sedang (17-18 tahun), dan tinggi (19-20 tahun). Hal ini dapat dilihat pada Tabel 2 .
Tabel 2. Hubungan Antara Tingkatan Umur Dengan Ragam Situs Yang Dibuka Oleh Respondendi Desa Cibatok I dan Desa Pangradin

\begin{tabular}{lcccc}
\hline & \multicolumn{3}{c}{ Ragam Situs } \\
Golongan Umur & \multicolumn{2}{c}{ Tidak Beragam } & \multicolumn{2}{c}{ Beragam } \\
& Jumlah & Persentase (\%) & Jumlah & Persentase (\%) \\
\hline Rendah & 10 & 26 & 29 & 74 \\
Sedang & 3 & 18 & 14 & 82 \\
Tinggi & 3 & 75 & 1 & 25 \\
\hline
\end{tabular}

Dari data Tabel 2 dapat dijelaskan bahwa rata-rata remaja golongan umur rendah (15-16 tahun) memiliki tingkat keragaman yang paling tinggi dalam membuka situs-situs yang tersedia di internet dibandingkan golongan umur lainnya. Hal ini kemungkinan disebabkan oleh beberapa hal berikut, yaitu:

1. Responden dalam penelitian ini lebih banyak memiliki umur 15 dan 16 tahun.

2. Remaja yang berumur 15 dan 16 tahun berada dalam masa pubertas (remaja awal), secara psikologis memiliki rasa ingin tahu yang tinggi terhadap sesuatu.

3. Kategori umur sedang dan tinggi cukup jarang mengakses internet, terutama responden di Desa Pangradin. Remaja yang berumur 17 tahun ke atas di desa tersebut banyak yang bekerja untuk membantu orang tua atau menempuh pendidikan di pesantren sehingga jarang untuk mengakses internet.

Dalam penelitian ini juga akan dilihat hubungan antara tingkat pendidikan mempengaruhi ragam situs yang dibuka oleh remaja di Desa Cibatok I dan Desa Pangradin. Adapun tingkat pendidikan dikategorikan menjadi tiga, yaitu: rendah (Tidak Sekolah/Tamat SD), sedang (SMP/Tamat SMP), dan tinggi (SMA/Tamat SMA). Hal ini dapat dilihat pada Tabel 3.

Tabel 3. Hubungan Antara Tingkat Pendidikan Dengan Ragam Situs Yang Dibuka Oleh Remaja di Desa Pangradin dan Desa Cibatok I

\begin{tabular}{lcccc}
\hline & \multicolumn{3}{c}{ Ragam Situs } \\
Tingkat Pendidikan & \multicolumn{2}{c}{ Tidak Beragam } & \multicolumn{2}{c}{ Beragam } \\
& Jumlah & Persentase (\%) & Jumlah & Persentase (\%) \\
\hline Rendah & 6 & 100 & 0 & 0 \\
Sedang & 5 & 38 & 8 & 62 \\
Tinggi & 5 & 12 & 36 & 88 \\
\hline
\end{tabular}

Dari data Tabel 3 di atas menunjukkan bahwa tingkat pendidikan mempengaruhi ragam situs yang dibuka. Semakin tinggi tingkat pendidikan responden, maka semakin banyak situs yang pernah dibuka dengan persentase sebesar 88 persen (36 orang) dari total keseluruhan responden. Sebaliknya, semakin rendah tingkat pendidikan responden maka situs yang dibuka tidak beragam (hanya pernah membuka satu situs saja) 
dengan persentase sebesar 100 persen (enam orang) dari total keseluruhan responden.

\section{Intensitas Penggunaan Internet}

Intensitas dalam penggunaan internet adalah frekuensi atau lamanya waktu yang dihabiskan oleh responden untuk bermain internet dalam jangka waktu sehari dan satu minggu. Dalam penelitian ini, dilihat juga waktu mereka bermain internet yang dikategorikan menjadi empat, yaitu: Pagi (05.00-11.00), Siang (12.00-16.00), Sore (17.00-20.00), dan Malam (20.00-04.00). Dari hasil penelitian diperoleh beberapa hal berikut ini, yaitu:

1. Rata-rata remaja Desa Cibatok I mengakses internet pada waktu siang hari dengan persentase sebesar 43 persen atau sebanyak 13 orang.

2. Rata-rata remaja di Desa Pangradin memiliki waktu bermain internet pada sore hari dengan persentase sebesar 40 persen (12 orang).

Frekuensi atau lamanya waktu yang dihabiskan oleh responden dalam sehari di kedua desa berada dalam kategori rendah, yaitu kurang dari lima jam dengan persentase yang sama, yaitu 97 persen atau sebanyak 29 orang. Hal ini dikarenakan rata-rata mereka banyak mengakses internet dalam sehari hanya sekitar 1-4 jam/hari. Untuk di Desa Cibatok I, remaja desa disibukkan oleh kegiatan belajar-mengajar di sekolah, kegiatan ekstrakurikuler, dan kegiatan lainnya yang menjadikan mereka tidak terlalu banyak waktu untuk bermain internet, kecuali pada waktu luang. Sementara di Desa Pangradin, rata-rata remaja lebih banyak menghabiskan waktu mereka di rumah, membantu orang tua, kerja sambilan, sekolah, atau kegiatan lainnya yang juga menyebabkan mereka tidak memiliki banyak waktu untuk bermain internet terlalu lama. Disamping itu, keterbatasan fasilitas internet juga membuat mereka jarang mengakses internet dalam sehari.

Dalam penelitian ini, frekuensi atau lamanya waktu yang dihabiskan responden untuk bermain internet di warung internet dalam jangka waktu seminggu dikategorikan menjadi tiga, yaitu : Rendah (1-2 kali seminggu), Sedang (3-5 kali seminggu), dan Tinggi (6-7 kali seminggu). Dari hasil penelitian diperoleh beberapa hal berikut, yaitu:

1. Frekuensi atau lamanya waktu remaja bermain internet di Desa Cibatok I lebih tinggi dibandingkan frekuensi remaja bermain internet di Desa Pangradin.

2. Untuk Desa Cibatok I, persentase terbesar responden mengunjungi warung internet dalam jangka waktu seminggu adalah 40 persen atau sebanyak 12 orang yang berada dalam kategori sedang. Mereka rata-rata mengunjungi warung internet dari 3-5 kali dalam seminggu.

3. Di Desa Pangradin, rata-rata remaja mengunjungi warung internet hanya 1-2 kali dalam seminggu dengan persentase 83 persen atau sebanyak 25 orang.

\section{DAMPAK SOSIAL-EKONOMI MASUKNYA INTERNET DALAM KEHIDUPAN REMAJA DESA}

\section{Dampak Sosial Internet Dalam Kehidupan Remaja Desa}

\section{Alokasi Waktu}

Alokasi waktu merupakan efektifitas penggunaan waktu yang digunakan antara kewajiban utama remaja sebagai pelajar (kegiatan produktif) dengan kegiatan lainnya (termasuk bermain internet) sebagai kegiatan yang reproduktif dalam total waktu 24 jam atau satu hari. Dalam penelitian ini, alokasi waktu dikategorikan menjadi dua, yaitu: 1) Kegiatan Produktif, meliputi belajar-mengajar di sekolah dan ekstrakurikuler. 2) Kegiatan Reproduktif, meliputi menonton televisi, membantu orang tua, bermain internet, dan kegiatan lainnya. Beberapa hal yang dapat dijelaskan dari total alokasi waktu dalam sehari yang digunakan oleh remaja di kedua desa tersebut, yaitu:

1. Remaja pedesaan saat ini telah memiliki aktivitas yang beragam. Baik di Desa Cibatok I maupun Desa Pangradin, remajanya sudah melakukan berbagai aktivitas yang tidak jauh berbeda dengan aktivitas yang dilakukan oleh remaja perkotaan. Berbeda halnya dengan remaja desa dahulu yang cenderung lebih banyak menghabiskan waktu di rumah untuk membantu orang tua.

2. Bagi yang masih melanjutkan pendidikan, alokasi waktu kegiatan produktif remaja Desa Pangradin lebih rendah dibandingkan Desa Cibatok I. Hal ini dikarenakan, remaja Pangradin tidak banyak yang mengikuti kegiatan ekstrakurikuler. Mereka bersekolah di pesantren yang ada di kawasan Pangradin. Biasanya, setelah pulang sekolah, mereka tidak ada kegiatan lagi sehingga langsung pulang ke rumah masing-masing

3. Alokasi waktu yang digunakan oleh remaja untuk bermain internet tergolong masih rendah. Rata-rata remaja Desa Cibatok I mengalokasikan waktu bermain internet sekitar dua jam dalam sehari. Sementara untuk di Desa Pangradin, alokasi waktu untuk bermain internet rata-rata hanya satu jam per hari. Beberapa hal yang menyebabkan alokasi waktu bermain internet di kedua desa tersebut masih tergolong rendah, yaitu:

a. Untuk Desa Cibatok I, remajanya masih banyak menghabiskan waktu mereka untuk kegiatan di sekolah, baik kegiatan intra maupun kegiatan esktrakurikuler sehingga mereka hanya mengakses internet ketika pulang sekolah maupun di saat pelajaran Teknologi Informasi dan Komunikasi (TIK).

b. Untuk Desa Pangradin, sebagian remaja baik yang putus sekolah maupun tidak harus bekerja untuk meringankan ekonomi keluarga sehingga mereka tidak terlalu banyak waktu untuk bermain internet. Disamping itu, keterbatasan akses internet membuat mereka jarang untuk membuka situs-situs internet. 


\section{Perubahan Intensitas Hubungan Sosial dalam Keluarga}

Perubahan intensitas hubungan sosial dalam keluarga merupakan perubahan tingkat kedalaman hubungan komunikasi yang terjalin antara responden dan orang tua setelah masuknya pengaruh internet. Dalam penelitian ini, rata-rata rata orang tua remaja di Desa Cibatok I tidak melakukan pengawasan saat anaknya bermain internet melalui ponsel ataupun komputer di rumah, yaitu dengan persentase sebesar 57 persen atau sebanyak 17 orang. Hal ini dikarenakan sebagian orang tua mereka memiliki aktivitas sendiri, baik bekerja maupun mengurus keperluan rumah tangga. Disamping itu, banyak orang tua yang tidak mengetahui cara menggunakan internet sehingga mereka tidak mengetahui situs-situs yang diakses oleh putra-putrinya.

1. Hanya 43 persen (13 orang) remaja di Desa Cibatok I yang orangtuanya mengawasi putra-putrinya ketika bermain internet di rumah. Hal ini dilakukan dengan cara mendampingi anaknya bermain internet jika mereka sedang ada waktu luang atau meminta kepada pihak pemasang internet untuk melakukan pemblokiran terhadap situs-situs pornografi. Ada juga orang tua yang hanya mengingatkan anaknya untuk berhenti bermain internet jika sudah terlalu lama.

2. Sementara itu, orangtua remaja di Desa Pangradin rata-rata tidak pernah melakukan pengawasan kepada anaknya ketika bermain internet di rumah dengan persentase sebesar 87 persen (26 orang), karena putra-putri mereka tidak memiliki ponsel atau komputer pribadi yang dapat mengakses internet. Hal ini juga dikarenakan rendahnya tingkat pendidikan dan pengetahuan orang tua mengenai teknologi internet sehingga orang tua di Desa Pangradin cenderung hanya bisa menasehati putraputrinya untuk tidak melakukan perilaku menyimpang.

Dalam penelitian ini, hubungan sosial dalam keluarga juga dilihat dari tempat responden banyak menghabiskan waktu dalam sehari. Ada sebagian remaja yang memang memilih untuk di rumah karena merasa lebih nyaman dibandingkan bermain di luar rumah. Hal ini sebagaimana terlihat pada Tabel 4.

Tabel 4. Perbandingan Tempat Responden Menghabiskan Waktu Dalam Sehari di Desa Cibatok I dan Desa Pangradin

\begin{tabular}{|c|c|c|c|c|c|c|}
\hline \multirow{3}{*}{ Desa } & \multicolumn{4}{|c|}{ 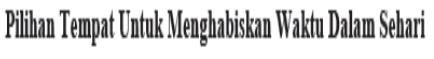 } & \multicolumn{2}{|c|}{ Iotal } \\
\hline & & Umalh & & Rumah & & \\
\hline & $\begin{array}{l}\text { Jumlah } \\
\text { (Orange) }\end{array}$ & $\begin{array}{l}\text { Persenthase } \\
(\%)\end{array}$ & $\begin{array}{l}\text { Jumlah } \\
\text { (Ornage) }\end{array}$ & $\begin{array}{c}\text { Persentase } \\
(\%)\end{array}$ & $\begin{array}{l}\text { Jumlah } \\
\text { (Ornagg) }\end{array}$ & $\begin{array}{l}\text { Persentase } \\
(\%)\end{array}$ \\
\hline Desa CibatokI & 15 & 50 & 15 & 50 & 30 & 100 \\
\hline Dess Pangradin & 19 & 63 & 11 & 37 & 30 & 100 \\
\hline
\end{tabular}

Beberapa hal yang dapat ditunjukkan dari data Tabel 4, yaitu:
1. Sebagian remaja (50 persen atau 15 orang) di Desa Cibatok I memilih lebih banyak menghabiskan waktu di luar rumah. Sementara itu, 50 persen atau 15 remaja yang lain lebih banyak menghabiskan waktu di luar rumah dibandingkan berada di rumah.

2. Di Desa Pangradin, rata-rata remaja menghabiskan banyak waktu di rumah dengan persentase sebesar 63 persen atau sebanyak 19 orang. Mereka jarang bepergian karena akses menuju kota sangat jauh dan sulitnya sarana transportasi. Sementara itu, 37 persen atau 11 orang mengaku lebih banyak melakukan aktivitas di luar rumah. Mereka merupakan remaja yang harus bekerja untuk membantu orang tua, seperti berdagang bakso, tukang ojeg, buruh, atau membantu orang tua di kebun.

Fase remaja merupakan tahap perkembangan manusia menuju kedewasaan. Dalam fase ini, biasanya remaja mudah terpengaruh oleh hal-hal baru yang ada di sekitarnya. Biasanya, dalam tahapan umur remaja mereka belum bisa mengatasi masalah dengan baik. Oleh karena itu, peran orang tua sebenarnya sangat penting untuk mendampingi mereka ketika dihadapkan dalam sebuah masalah. Namun, tidak banyak remaja yang mau terbuka kepada orangtuanya ketika mengahdapi suatu masalah. Remaja di Desa Cibatok I dan Desa Pangradin lebih memilih untuk berbagi cerita dengan teman atau sahabat terdekatnya. Mereka masih memiliki keterbukaan diri (self disclosure) yang rendah untuk berbagi cerita dengan keluarga. Hal ini dikarenakan remaja masih memiliki keseganan dan tidak percaya diri terhadap orang tua untuk menceritakan hal-hal yang bersifat pribadi. Remaja Desa Cibatok I dan Desa Pangradin sangat jarang untuk berbagi cerita dengan temannya di dunia maya.

\section{Intensitas Komunikasi Dunia Maya}

Intensitas komunikasi merupakan tingkat kedalaman hubungan interaksi responden dengan temannya di dunia maya. Intensitas komunikasi dunia maya lebih banyak terjalin melalui situs-situs jejaring sosial yang menyediakan fasilitas komunikasi berupa Chat Room, Wall to Wall, Message, Comment, status, dan lainnya. Dalam penelitian ini, diperoleh data bahwa remaja Desa Cibatok I memiliki intensitas komunikasi dunia maya yang lebih tinggi dibandingkan remaja di Desa Pangradin. Hal ini dikarenakan komunikasi dunia maya telah menggeser norma sosial remaja desa yang dulunya sangat mengedepankan komunikasi tatap muka. Hal ini telah dialami oleh remaja di Desa Cibatok I. Ketika sedang mengakses situs jejaring sosial, rata-rata remaja di Desa Cibatok I merasa lebih nyaman berinteraksi melalui chat room dengan teman di dunia maya yang disediakan oleh situs jejaring sosial dibandingkan dengan teman yang ada di sekitar atau di sebelahnya.

\section{Luasnya Jaringan Sosial Dunia Maya}

Luasnya jaringan sosial dunia maya adalah banyaknya jaringan dunia maya yang dijalin oleh responden melalui situs-situs jejaring sosial internet. Dalam penelitian ini, luasnya jaringan pertemanan dunia maya dilihat dari jumlah teman yang dimiliki oleh remaja desa di situs jejaring sosial. Dikarenakan hampir semua responden 
rata-rata memiliki satu situs jejaring sosial, yaitu Facebook, maka dalam penelitian ini hanya dilihat jumlah teman yang mereka miliki di situs tersebut. Dari hasil penelitian diperoleh bahwa rata-rata remaja Desa Cibatok I memilki jaringan sosial dunia maya yang lebih luas dibandingkan remaja di Desa Pangradin. Hal ini dibuktikan dari jumlah teman dunia maya yang dimiliki remaja Desa Cibatok I di Facebook relatif tinggi, yaitu $>1000$ orang dengan persentase sebesar 43 persen atau sekitar 13 orang. Sementara itu, remaja di Desa Pangradin rata-rata memiliki jumlah teman dunia maya di Facebook tergolong rendah, yaitu $<250$ orang. Rata-rata remaja Pangradin memiliki teman di bawah 100 orang atau bahkan ada tiga responden yang tidak memiliki Facebook.

\section{Tingkat Perubahan Ideologi}

Tingkat perubahan ideologi merupakan perubahan pola pikir atau gaya hidup rseponden setelah bergabung dengan suatu komunitas atau grup dunia maya tertentu. Pada saat ini, banyak komunitas-komunitas dunia maya yang muncul karena kesamaan hobi, kesamaan visi dan misi, kesamaan budaya, dan lain-lain. Situs jejaring sosial, seperti Facebook, atau komunitas blogger juga telah menyediakan ruang grup bagi pengguna situs ini. Grup ini terbagi menjadi dua, yaitu bersifat terbuka (semua orang bisa untuk bergabung) dan tertutup (hanya orang-orang tertentu yang bisa bergabung). Namun, adanya fasilitas grup di Facebook atau di situs lainnya ini hanya sebagian remaja desa saja yang mengetahui. Ada sebagian dari remaja yang tidak mengetahui adanya fasilitas ruang grup di situs jejaring sosial ataupun blog. Hal ini sebagaimana terlihat pada Tabel 5.

Tabel 5. Pengetahuan Remaja Terhadap Grup Dunia Maya di Desa Cibatok I dan Desa Pangradin

\begin{tabular}{|c|c|c|c|c|}
\hline \multirow{3}{*}{ Desa } & \multicolumn{4}{|c|}{ Grup Dunia Nlaỹa } \\
\hline & \multicolumn{2}{|c|}{$\begin{array}{l}\text { Ya, Yengettahui adanya grup komunitas } \\
\text { dumia maya }\end{array}$} & \multicolumn{2}{|c|}{$\begin{array}{c}\text { Tidak mengettahui adanya grupp komunita } \\
\text { dumia maya }\end{array}$} \\
\hline & Jumlah(Orang) & Persentase $(\%)$ & Jumlah (Orang) & Persentase $(\%)$ \\
\hline Desa CibatokI & 30 & 100 & 0 & 0 \\
\hline Desa Pangradin & 13 & 43 & 17 & 57 \\
\hline
\end{tabular}

Dari data di atas diketahui bahwa semua responden Desa Cibatok I sudah mengetahui adanya grup dunia maya yang disediakan oleh komunitas blogger atau situs jejaring sosial dengan persentase sebesar 100 persen. Mereka rata-rata mengetahui grup tersebut dari teman atau mencari sendiri informasi-informasi mengenai aplikasi yang ada di situs jejaring sosial.Sementara itu, rata-rata remaja Desa Pangradin tidak mengetahui adanya grup atau komunitas dunia maya, yaitu dengan persentase sebesar 57 persen (17 orang). Hal ini dikarenakan jarangnya remaja membuka situs-situs di internet sehingga pengetahuan mereka terhadap fasilitas yang disediakan oleh internet sangat rendah. Namun, walaupun sebagian besar remaja telah mengetahui tentang adanya grup dunia maya, tidak semua remaja di kedua desa tersebut yang mengikuti atau bergabung dalam suatu grup dunia maya tertentu. Hal ini sebagaimana terlihat dari Tabel 6.
Tabel 6. Minat Remaja Untuk Bergabung Dalam Grup Dunia Maya di Desa Cibatok I dan Desa Pangradin

\begin{tabular}{ccccc}
\hline & \multicolumn{4}{c}{ Grup Dunia Maya } \\
Desa & Ya, Mengikuti suatu grup dunia maya \\
tertentu & Tidak mengikuti suatu grup \\
& Jumlah (Orang) & Persentase (\%) & Jumala maya (Orang) & Persentase (\%) \\
\hline Desa CibatokI & 30 & 100 & 0 & 0 \\
Desa Pangradin & 9 & 69 & 4 & 31 \\
\hline
\end{tabular}

Dari data tabel di atas diketahui bahwa seluruh responden di Desa Cibatok I mengikuti suatu grup atau komunitas dunia maya tertentu dengan persentase sebesar 100 persen atau sebanyak 30 orang. Sementara itu, dari 13 responden Desa Pangradin yang mengetahui adanya grup dunia maya, hanya sembilan orang atau 69 persen yang mengikuti grup dunia maya tertentu. Sekitar empat orang atau 31 persen remaja tidak mau mengikuti suatu grup dunia maya karena merasa tidak ada manfaat yang diperoleh, tidak terlalu dianggap menjadi anggota, atau takut terpengaruh dengan pola pikir anggota grup lainnya.

\section{Tingkat Penghargaan Terhadap Nilai-nilai dan Norma Tradisi}

Tingkat penghargaan terhadap nilai-nilai dan norma tradisi adalah pergeseran dalam memaknai dan menghargai nilai-nilai dan norma tradisi yang sudah melekat sebelumnya dalam diri masyarakat di pedesaan akibat masuknya pengaruh internet. Dari hasil penelitian diperoleh data bahwa tingkat penghargaan terhadap nilainilai dan norma remaja di Desa Pangradin lebih tinggi dibandingkan tingkat penghargaan terhadap nilai-nilai dan norma remaja di Desa Cibatok I. Hal ini disebabkan oleh beberapa faktor berikut:

1. Komunikasi dunia maya yang dilakukan oleh remaja di Desa Cibatok I telah menggeser norma sosial yang mengedepankan komunikasi tatap muka. Perubahan ini telah mencapai tahap dimana penggunaan teks dan email membuat kemampuan komunikasi interpersonal semakin berkurang.

2. Remaja Desa Pangradin juga memiliki tingkat penghargaan nilai-nilai dan norma yang masih cukup tinggi. Hal ini dikarenakan masih kuatnya nilai-nilai agama yang diajarkan oleh orang tua kepada anak-anak mereka. Rata-rata remaja Pangradin di sekolahkan di pesantren yang ada di dekat rumah mereka untuk lebih mendalami nilai-nilai agama serta menghindari mereka terjebak dalam pergaulan bebas.

\section{Dampak Positif dan Negatif Bagi Kehidupan Remaja di Pedesaan}

Internet sudah membawa begitu banyak kemudahan kepada penggunanya. Beragam akses terhadap informasi dan hiburan dari penjuru dunia dapat dilakukan melalui media online ini. Remaja sebagai salah satu pengguna fasilitas internet memanfaatkan teknologi ini dengan berbagai tujuan. Pemanfaatan internet oleh remaja 
memberikan dampak positif maupun negatif bagi perkembangan pola pikir dan perilakunya. Tabel 7 menyajikan data mengenai dampak positif masuknya internet yang dirasakan oleh responden di Desa Cibatok I dan Desa Pangradin.

Tabel 7. Dampak Positif Masuknya Internet dalam Kehidupan Remaja di Desa Cibatok I dan Desa Pangradin

\begin{tabular}{lcccc}
\hline \multicolumn{1}{c}{ Dampak Positif } & \multicolumn{2}{c}{ Desa Cibatok I } & \multicolumn{2}{c}{ Desa Pangradin } \\
& Jumlah & Persentase (\%) & Jumlah & Persentase (\%) \\
\hline Menambah Wawasan & 9 & 30 & 9 & 30 \\
Menambah Teman & 18 & 60 & 21 & 70 \\
Memudahkan Tugas Sekolah & 3 & 10 & 3 & 10 \\
Memudahkan Komunikasi & 2 & 7 & 0 & 0 \\
Sarana Hiburan & 2 & 7 & 9 & 30 \\
Tempat Berbagi/Curhat & 3 & 10 & 0 & 0 \\
Menjalin Silaturahmi & 5 & 17 & 0 & 0 \\
Sarana Bisnis & 1 & 3 & 2 & 7 \\
\hline
\end{tabular}

Beberapa hal yang dapat dijelaskan dari Tabel 7 mengenai dampak positif internet bagi remaja di kedua desa, yaitu:

1. Remaja di kedua desa menyatakan bahwa internet telah menambah wawasan mereka mengenai dunia luar dengan memberikan informasi-informasi terbaru yang dapat meningkatkan pengetahuan mereka.

2. Rata-rata remaja di kedua desa memanfaatkan internet untuk menambah teman atau relasi melalui situs jejaring sosial seperti Facebook. Melalui Facebook, mereka dapat menjalin pertemanan dengan banyak orang yang tidak terbatas oleh geografis.

3. Remaja di Desa Cibatok I menyatakan bahwa internet telah memudahkan komunikasi mereka dengan oran-orang luar, terutama dengan temanteman mereka yang sudah lama tidak bertemu. Internet juga melatih mereka untuk menjalin komunikasi dengan warga asing sehingga mereka dapat mengasah kemampuan mereka dalam berbahasa asing.

4. Internet bagi remaja di kedua desa dijadikan sebagai sarana hiburan. Bagi remaja laki-laki, mereka sering bermain game online untuk menghilangkan kejenuhan setelah beraktivitas.

5. Internet bagi remaja di Desa Cibatok I juga dijadikan sebagai media untuk menjalin silaturahmi dengan berbagai teman-teman lama atau sesama anggota dari suatu grup dunia maya.

6. Pada saat ini, remaja di kedua desa juga telah memanfaatkan internet sebagai sarana bisnis untuk menjual suatu produk mereka secara online atau mempromosikan band agar dikenal oleh masyarakat dunia maya lainnya.

Namun dibalik kemudahannya, kehadiran internet juga dapat membawa pengaruh negatif bagi penggunanya, terutama kaum remaja. Sebagian besar remaja belum mampu memilah aktivitas internet yang bermanfaat sehingga mereka cenderung mudah terpengaruh oleh lingkungan sosial tanpa mempertimbangkan terlebih dahulu efek negatif yang akan diterima. Dalam penelitian ini, bebeberapa kasus perilaku negatif pada remaja di kedua desa, yaitu:

1. Pengaruh internet telah menyebabkan sebagian remaja di kedua desa sering melupakan tugas sekolah dan waktu beribadah.

2. Rata-rata remaja di Desa Cibatok I sudah pernah melihat situs pornografi. Hal ini dilakukan dengan sengaja maupun tidak sengaja ketika membuka suatu laman atau situs tertentu. Responden laki-laki memiliki persentase lebih banyak dibandingkan perempuan dalam hal melihat situs pornografi. Berbeda dengan yang terjadi di Desa Pangradin, hanya satu remaja saja yang mengaku pernah melihat situs tersebut.

3. Situs jejaring sosial telah membuat penggunanya melakukan tindak perkelahian dengan temannya di dunia maya maupun di dunia nyata. Hal ini dipicu oleh berbagai hal, seperti akibat penghinaan yang dilakukan oleh temannya di dunia maya, persoalan cinta, kesalahpahaman, dan lain-lain.

4. Beberapa remaja di kedua desa mengaku pernah tidak masuk sekolah (bolos) akibat terlalu asyik bermain game online. Hal ini dilakukan oleh empat remaja di Desa Cibatok 1 dan dua remaja di Desa Pangradin.

5. Terdapat satu responden di Desa Cibatok I yang mengaku sering begadang karena keasyikan bermain game online. Hal ini diakibatkan disediakannya fasilitas internet di rumah oleh orangtuanya. Kurangnya pengawasan dan ketidaktahuan orang tua dalam menggunakan internet membuat remaja menjadi leluasa mengakses situs-situs dan aplikasi game yang tersedia. Hal ini tidak terjadi di Desa Pangradin dikarenakan keterbatasan fasilitas internet yang dimiliki.

6. Terdapat dua responden di Desa Cibatok I yang mengaku pernah berjudi atau taruhan bersama teman-temannya ketika bermain game online. Hal ini mereka lakukan hanya sekedar terpengaruh ajakan temana atau memang untuk memperoleh tambahan uang saku. Hal ini juga tidak terjadi di Desa Pangradin.

7. Terdapat dua responden di Desa Cibatok I yang mengaku pernah merasa malas membantu orang tua karena asyik bermain internet. Mereka lebih memilih bermain internet berjam-jam dan mengacuhkan himbauan orang tua jika mereka meminta bantuan. Sementara di Desa Pangradin, remajanya lebih memilih untuk bekerja membantu orang tua daripada bermain internet.

8. Terdapat tiga responden di Desa Cibatok I yang mengaku mengeluarkan banyak biaya untuk bermain internet. Mereka mengeluarkan uang untuk biaya pulsa, biaya ke warung internet, atau biaya internet di rumah. Berbeda dengan yang terjadi di Desa Pangradin, hampir sebagian remajanya yang bekerja menyisihkan uang untuk diberikan kepada orang tua 
mereka. Bagi yang belum bekerja, lebih memilih mengeluarkan biaya untuk keperluan lainnya dibandingkan untuk bermain internet.

9. Situs jejaring sosial sering disalahgunakan oleh penggunanya, terutama kaum remaja. Kurangnya kesadaran mengenai manfaat jejaring sosial sering menjadikan remaja sebagai korban ataupun tersangka kejahatan dunia maya.

10. Terdapat satu responden di Desa Pangradin yang mengaku pernah melakukan tindak penipuan dengan memanfaatkan fasilitas internet.

\section{Dampak Ekonomi Internet dalam Kehidupan Remaja Desa}

\section{Tingkat Pendapatan}

Struktur pendapatan dalam penelitian ini dikategorikan menjadi tiga, yaitu: rendah (< Rp250.000,00), sedang (Rp250.000,00-Rp500.000,00), dan tinggi (> Rp500.000,00). Pengambilan data responden dengan merinci uang saku per hari atau per bulan yang diperoleh mereka dari orang tua, wali bekerja, atau dari beasiswa. Dari hasil penelitian, rata-rata pendapatan remaja di Desa Cibatok I yang diperoleh dari wali maupun orang tua, yaitu sekitar Rp300.000,00 setiap bulannya atau sebesar Rp10.000 per hari. Mereka dikategorikan dalam pendapatan sedang (Rp250.000-Rp500.000) dengan persentase sebesar 90 persen atau sebanyak 27 orang. Sementara itu, rata-rata pendapatan remaja di Desa Pangradin kurang dari Rp250.000,00 atau berada dalam kategori rendah, yaitu sebesar 57 persen atau sekitar 17 orang.

Pada saat ini, internet bukan hanya menjadi media sosial bagi sebagian masyarakat tetapi juga digunakan sebagai media untuk penjualan produk yang dikenal dengan istilah bisnis online. Sebagian remaja di Desa Cibatok I dan Desa Pangradin ada yang memilih untuk mencoba memasarkan produk mereka melalui transaksi online untuk menambah uang saku mereka. Namun, ada juga yang menyalahgunakan internet untuk memperoleh uang dengan melakukan taruhan atau judi bersama temantemannya. Dari hasil penelitian, rata-rata remaja yang memanfaatkan internet untuk memperoleh uang saku tambahan, hanya sekitar 23 persen (tujuh orang) di Desa Cibatok I dan 13 persen (empat orang) di Desa Pangradin. Di Desa Cibatok I, sekitar tiga orang memanfaatkan media internet untuk bisnis online seperti menjual pakaian online, promosi band, dan penjualan kaos sablón online. Dan dua orang remaja di Desa Cibatok memanfaatkan media internet sebagai ajang taruhan bermain game online bersama teman-temannya. Di Desa Pangradin, ada dua orang yang memanfaatkan media internet untuk bisnis online, seperti bisnis pulsa dan pakaian online. Sementara dua orang lagi pernah menggunakan media internet sebagai ajang taruhan bersama teman-temannya untuk menambah uang saku mereka.

\section{Alokasi Uang Saku/Tingkat Pengeluaran}

Dari hasil penelitian diketahui bahwa rata-rata alokasi uang saku remaja Desa Cibatok I digunakan untuk biaya pendidikan, yaitu dengan persentase 27 persen atau sebesar Rp100.000,00 perbulan. Sementara itu, biaya yang digunakan untuk mengakses internet, baik di rumah, warung internet, maupun melalui ponsel masing-masing memiliki persentase 2 persen (bermain internet di rumah), 18 persen (warung internet), dan 12 persen (ponsel) dengan total rata-rat pengeluaran seluruhnya untuk bermain internet adalah Rp115.367,00 per bulan. Biaya pengeluaran transportasi ke sekolah sebesar 20 persen atau sekitar Rp 73.000,00 per bulan. Untuk biaya hiburan (belanja, bermain, dan lain-lain) sebesar 14 persen atau sekitar Rp 53.000,00 per bulan. Sisanya digunakan untuk biaya lain (tabungan) sebesar 7 persen atau sekitar Rp26.000,00 per bulan.

Sementara itu, rata-rata alokasi uang saku remaja Desa Pangradin digunakan untuk biaya lain, seperti menabung atau diberikan kepada orang tua bagi yang bekerja dengan persentase 30 persen atau sebesar Rp86.633 per bulan. Sementara itu, biaya yang digunakan untuk mengakses internet, rata-rata remaja bermain internet di warung internet dan ada sebagian kecil melalui ponsel masingmasing memiliki persentase 10 persen (warung internet) dan 10 persen (ponsel) dengan total rata-rata pengeluaran seluruhnya untuk bermain internet adalah Rp50767,00 per bulan. Sedangkan biaya pengeluaran transportasi ke sekolah sebesar 28 persen atau sekitar Rp 82.000,00 per bulan. Untuk biaya hiburan (belanja, bermain, dan lainlain) sebesar 15 persen atau sekitar $\mathrm{Rp} 43.967,00$ per bulan.

\section{PENUTUP}

\section{Kesimpulan}

1. Karakteristik responden tidak selalu mempengaruhi pola penggunaan internet.

2. Hasil penelitian lainnya menunjukkan adanya perbedaan kedalaman perubahan sosial dalam kehidupan remaja yang dilihat dari aspek sosial dan ekonomi antara desa yang akses internetnya tinggi dengan desa yang akses internetnya masih sangat terbatas.

\section{Saran}

1. Para orang tua harus lebih bijaksana dalam menghadapi keinginan putra-putrinya untuk mengakses internet.

2. Para professional informasi, khususnya yang terkait dengan dunia internet dan pendidikan, sebaiknya lebih memanfaatkan situasi ini dengan menyediakan situs-situs edukatif yang memiliki content informasi yang relevan dengan kurikulum sekolah. Disamping itu, perlunya dilakukan sosialisasi situs-situs tersebutdi sekolah-sekolah.

3. Bagi para akademisi yang tertarik dengan kajian di bidang perilaku penggunaan internet pada kalangan remaja di pedesaan, ada beberapa aspek yang belum dibahas lebih lanjut dalam penelitian ini sehingga peneliti lain diharapkan dapat mengkaji lebih lanjut dari apa yang telah dihasilkan dalam penelitian ini agar pada akhirnya kajian di bidang ini diharapkan bisa semakin menarik dan lengkap. 


\section{DAFTAR PUSTAKA}

Bungin, Burhan. 2006. Sosiologi Komunikasi. Jakarta: Kencana Prenada Media Grup.

Bungin, Burhan. 2008. Sosiologi Komunikasi. Jakarta: Kencana Prenada Media Grup.

Bungin, Burhan. 2009. Sosiologi Komunikasi. Jakarta: Kencana Prenada Media Grup.

Gunarsa \& Gunarsa. 1995. Psikologi Praktis: Anak, Remaja, dan Keluarga. Jakarta: Gunung Mulia.

Hurlock, E.B. 1980. Psikologi Perkembangan: Suatu Pendekatan Sepanjang Rentang Kehidupan. Jakarta: Erlangga.

Harper, Charles L. 1989. Exploring Social Change. New Jersey: Prectice Hall.

Hastuti, Sri dan Lina Sudarwati. 2007. Gaya Hidup Remaja Pedesaan di Desa Sukaraya, Kecamatan Pancur Batu, Kabupaten Deli Serdang, Sumatera Utara. Harmoni Sosial. 1(2): 69-82.

Hernandez, Roger E. 2005. Remaja dan Media. Bandung: Pakar Raya.

Horrigan, John B. 2002. New Internet Users: What They Do Online, What They Don't, and Implications for the 'Net's Future. [diakses tanggal 7 Januari 2012], tersedia pada www.pewinternet.org/pdfs/New_User_Report.pdf.

Koentjaraningrat (Ed.). 1979. Manusia dan Kebudayaan di Indonesia. Jakarta: Djambatan.

Krummel, D.M. dan Penny M. K. (ed). 1996. Nutrition in Women's Health Maryland: Aspen Publisher's Inc.

Loader, Brian D (Ed). 1998. Cyberspace Divide : Equality, Agency, and Policy in The Information Society. London: Routledge.

Manan, Abdul. 2011. Laporan Tahunan ALiansi Jurnalis Independen 2011 : Menjelang Snyal Merah. Jakarta: Aliansi Jurnalis Independen.

Mappiere, (1982). Psikologi Remaja. Surabaya: Penerbit Erlangga.

Mukhtar, Niken Ardiyanti, dan Erna Sulistiyaningsih. 2003. Konsep Diri Remaja Menuju Pribadi Mandiri. Jakarta: Rakasta Samasta.

Ogburn, William Fielding. 1922. Social Change with Respect to Culture and Original Nature. New York: B.W. Huebsch.

Piliang, Yasraf. 2004. Dunia Yang Dilipat. Bandung: Jala Sutra.

Rachmat, Jalaluddin. 2002. Psikologi Komunikasi. Bandung: PT. Remaja Rosdakarya.

Roselin. 2010. Transformasi Masyarakat Nyata Menuju Masyarakat Maya Melalui Internet (Studi Kasus Pengguna Internet Di Kalangan Penjual Bursa Saham Gedung Uniland Jl. Mt Haryono No. 4-1). [Skripsi]. Medan: Universitas Sumatera Utara. 97 hal.
Sarwono, Sarlito Wirawan. 2004. Psikologi Remaja. Jakarta: Raja Grafindo Persada.

Singarimbun, Masri dan Sofian Effendi. 1989. Metode Penelitian Survai. Jakarta: LP3ES.

Soekanto, Soerjono. 1974. Faktor-faktor Dasar Interaksi Sosial dan Kepatuhan pada Hukum-Hukum Nasional. Jakarta: Rajawali Pers.

Soekanto, Soerjono. 1987. Sosiologi Suatu Pengantar [Edisi Ketiga]. Jakarta: Rajawali Pers.

Soekanto, Soerjono. 2002. Sosiologi Suatu Pengantar. Jakarta: Rajawali Pers.

Soemardjan, Selo. 1962. Social Change in Yogyakarta. Cornell University Press: New York. Hal. XVIII dan 379.

Sugiyono. 2008. Metode Penelitian Kuantitatif, Kualitatif, dan R\&D. Bandung: Alfabeta.

Surya, Yuyun W.I. 2002. Pola Konsumsi dan Pengaruh Internet sebagai Media Komunikasi Interaktif pada Remaja (Studi Analisis Persepsi pada Remaja di Kotamadya Surabaya). Surabaya: Lembaga Penelitian Universitas Airlangga.

Starling, Andrew. 2007. The Internet and Society.[diakses tanggal 7 Januari 2012], tersedia pada www.webdevelopersjournal.com.

Teten, David dan Allen Scott. 2005. Virtual Handshake: Opening Doors and Closing Deals Online. New York: Amacom. 